\title{
EFFECT OF SOME ANTIOXIDANTS AGAINST POWDERY MILDEW DISEASE OF GRAPES IN EGYPT
}

\author{
E.Z. Khalifa, H.M. Awad and H.A. Deraz \\ Agricultural Botany Dept., Faculty of Agriculture, Menoufiya Univ., Egypt. \\ Received: Jul. 11, 2018 \\ Accepted: Aug. 1, 2018
}

\begin{abstract}
Grapes powdery mildew disease caused by Uncinula necator (Schw.) is one of the most critical diseases attacking grapes fruits, buds and leaves causing considerable yield losses. This study compared the effectiveness of three antioxidants on powdery mildew disease (ascorbic acid, citric acid and boric acid) in controlling the powdery mildew of grapes. The antioxidants were significantly better improving disease control and fruit yield production of grapes than the control. Ascorbic acid and citric acid were the most effective antioxidants on powdery mildew disease and increasing the yield.
\end{abstract}

Key words: Powdery mildew disease, Uncinula necator, grapes, antioxidants.

\section{INTRODUCTION}

Grapevine (Vitis vinefera L.) is one of the most important fruit crops all over the world, especially in tropical regions. The Egyptian grapes are very important both for local consumption and exportation.

Grapevine trees are liable to the attack of many pathogens such as Uncinula necator (schw.). Burr. causes powdery mildew disease. This fungus attacks buds, leaves and fruits causing considerable yield losses. Powdery mildew symptoms can be seen on foliage, fruit, flower parts and cans. Mildew usually appears first as whitish or greenish-white powdery patches on the undersides of leaves. It may cause mottling or distortion of severally infected leaves, as well as leaf curling and withering. Powdery mildew occurs all over the world on cultivated plants (Spencer 1978). Powdery mildew on grapes is very important in countries where hot summer, high temperature and high relative humidity are prevalent (Osman, 1977). Therefore, the present investigation was aimed to study pathogenicity test for different isolates of the fungus Uncinula necator to determine the most pathogenic isolates, as well as using of some antioxidant for control powdery mildew disease of grapes under open fields condition, instead of a lot of problems threaten to limit the continued use of fungicides.

\section{MATERIALS AND METHODS}

1. Survey of powdery mildew disease:

Severity of infection (S.I.) with powdery mildew disease was accomplished for two successive seasons (2015 and 2016) growing seasons at Al Gharbiyah, Bani Suwayf and Al Minya governorates. Thompson and Roumy Ahmer grape cultivars was subjected for these determinations every two weeks starting June. 5. Disease index 0 - 10 was followed where 0 means healthy plants and 10 means complete leaf damage and coverage with Uncinula necator growth (Table 1).

- Formula of Solemn et al. (1988) was followed for this purpose:

$$
\text { Severity of infection (S.I.) }=\frac{\mathrm{a} \times \mathrm{b}}{\mathrm{N} \times \mathrm{K}} \times 100
$$

Where (a) number of diseased plants, (b) grade of infection, (N) number total examined plants and $(K)$ maximum grade of infection. 
E.Z. Khalifa, et al.,

Table (1). Grading system for measuring severity of powdery mildew disease of grape.

\begin{tabular}{|c|c|}
\hline Rating score & \% infection \\
\hline 0 & 0 \\
1 & 10 \\
2 & 20 \\
3 & 30 \\
4 & 40 \\
5 & 50 \\
6 & 60 \\
7 & 70 \\
8 & 80 \\
9 & 90 \\
10 & 100 \\
\hline
\end{tabular}

All tested grape cultivars were evaluated for their resistance or susceptibility against Uncinula necator using a modified scale according to Kremer and Unterstahofer (1967).

\section{Antioxidants:}

Because a lot of problems threaten to limit the continued use of fungicides; these experiments conducted to use environmentally safe alternative methods of fungal control as antioxidants on powdery mildew disease of grapes. The experiments were carried out of EIMahrose Farm, Al Minya, Egypt during 2015-2016 growing seasons were used for preparation three antioxidants, i.e. ascorbic acid, citric acid and boric acid. The materials were used with two concentrations $1,2 \mathrm{~g} / \mathrm{L}$.

\section{Pathogenicity test:}

The conidia of Unicinula necator spores, used in these experiments, originated from field collection and from different localities. Conidia were washed off by shaking the detached leaves gently in distilled and sterilized water for some minutes and filtered through several layers of cheese cloth. Conidial concentrations were adjusted to $10^{-4}$ spore $\mathrm{I} \mathrm{ml}$ by using heamocytometer slide technique. Inoculation with Uncinula necator was carried out on 3 - 5 true leaves grape plants under open field condition.

Conidia suspension that prepared was sprayed on the upper and lower surfaces of the leaves. Each plant received $20 \mathrm{ml}$ spore suspension. Plant of susceptible grape cultivars (Rumy Ahmer and Thompson seedless) were conducted in these trials. All plants were covered with black polyethylene bags for 24 hours then the plants were placed under field conditions at $25-30^{\circ} \mathrm{C}$ and observed daily for symptoms development (Cerkauskas et al., 2011).

Observation were made for disease development on the abaxial surface of all leaves and fruits of each plant using the scale of (Horsfall and Barratt, 1945) at four times after inoculation (inoculation was done at 60 days plant growth age and the observation at $\mathbf{1 5}$ days intervals). 
4. Differentiation between the isolates of the fungus using molecular biology techniques:

\subsection{DNA extraction:}

DNA was extracted using sterilized sand soil. A Powdery mildew spores was homogenized in morter. $100 \mathrm{mg}$ from homogenized spores was used is isolate DNA according to the following methods. A modification of the traditional sodium dodecyl sulfate (SDS) extraction procedure was adopted. Fresh fungal pelt were homogenized in $400 \mu \mathrm{l}$ sterile salt homogenizing buffer $(200 \mathrm{mM}$ Tris- $\mathrm{HCl}$, pH 8.5 $250 \mathrm{mM} \mathrm{NaCl,} 25 \mathrm{mM}$ EDTA, 0.5\% SDS). Next 6 l $20 \mathrm{mg} / \mathrm{ml}$ RNase A was added and mixed well. The samples were incubated at $65^{\circ} \mathrm{C}$ for $10 \mathrm{~min}$, after which 130 l 3 M sodium acetate, pH 5.2, was added to each sample. Samples were vortexed for $30 \mathrm{~s}$ at maximum speed, and incubated at $-20^{\circ} \mathrm{C}$ for $10 \mathrm{~min}$. The lysate was centrifuged at $13,000 \mathrm{rpm}$ at $4^{\circ} \mathrm{C}$ for $15 \mathrm{~min}$, and the supernatant was transferred to fresh tubes. An equal volume of isopropanol was added to each sample, and after mixing well, and samples were incubated at $-20^{\circ} \mathrm{C}$ for 10 min. Samples were then centrifuged for $20 \mathrm{~min}$ at $4^{\circ} \mathrm{C}$, at $6000 \mathrm{rpm}$. The DNA pellets were washed twice using $700 \mu \mathrm{l}$ washing solution (100 and $70 \%$ ethanol, respectively). The DNA pellets were subsequently air dried in an oven at $40^{\circ} \mathrm{C}$ for at least $10 \mathrm{~min}$. The resultant DNA pellet was then re-suspended in $100 \mu \mathrm{l} 1 \mathrm{X}$ TE (10 mM Tris-HCl, 1 mM EDTA) buffer, pH 8.0 (Abd-elsalam et al., 2007).

\subsection{DAN quantification and gel documentation:}

Seven microliters of the isolated DNA and $3 \mu \mathrm{l}$ of $10 \mathrm{X}$ loading dye were loaded in a lane of $1.5 \%(w / v)$ agarose gel containing $0.05 \mu \mathrm{g} / \mathrm{ml}$ ethidium bromide, to check the quality of the DNA. For quantitative measurements, a chargecoupled decive camera imaging system and UVI soft analysis (Gel Documentation and Analysis Systems, Uvitec, Cambridge, UK) were used to capture the image and to calculate the band intensities.

\subsection{RAPD-PCR analysis:}

RAPD-PCR analysis was undertaken using 3-mer primers (MWG, Germany; Table 2 and Fig. 1 ). RAPD analysis was performed in $25 \mu \mathrm{l}$ reaction volumes containing PCR buffer (Promega, Mannheim, Germany), $0.2 \mathrm{mmol} / \mathrm{l}$ dNTPs, $0.5 \mathrm{mmol} / \mathrm{l}$ primer, $4.0 \mathrm{mmol} / \mathrm{l} \mathrm{MgCl}_{2}, 1.25$ units of Taq Polymerase (Promega, Mannheim, Germany) and 10 - $20 \mathrm{ng}$ genomic DNA. PCR reactions were carried out in a T-Gradient thermal cycler (Biometra, Germany) using the following profile: $94^{\circ} \mathrm{C}$ for $1 \mathrm{~min}, 36^{\circ} \mathrm{C}$ for $1 \mathrm{~min}$ and $72^{\circ} \mathrm{C}$ for $1 \mathrm{~min}$ for 30 cycles, and a final extension at $72^{\circ} \mathrm{C}$ for $5 \mathrm{~min}$. Following amplification, the samples were separated by electrophoresis in $1.4 \%$ agarose gel, stained with $0.5 \mu \mathrm{g} / \mathrm{ml}$ of ethidium bromide and viewed under ultraviolet light. A 300- to 1500-bp ladder (Promega, Mannheim, Germany) was used as a molecular mass marker.

Table (2). RAPD polymorphic decamer primers.

\begin{tabular}{|c|c|c||}
\hline Primer & 5'-Sequence-3' & G + C (\%) \\
\hline 1 & GGTCCCTGAC & 70 \\
\hline 2 & TGCCGAGCTG & 70 \\
\hline 3 & GGGTAACGCC & 70 \\
\hline
\end{tabular}



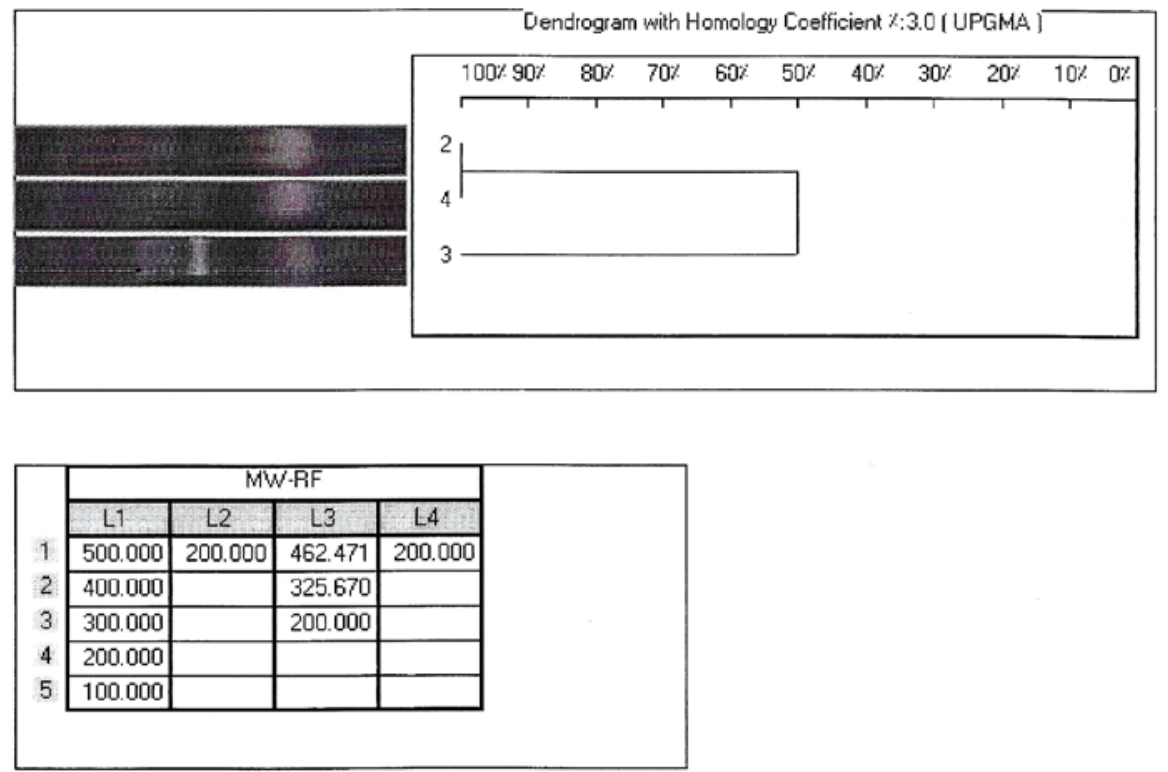

Fig. (1). Dendrogram with Homology Coefficient \%: 3.0 (UPGMA)

\section{Statistical analysis:}

The collected data were subjected to statistical analysis of using the Split plot design and means were compared by the LSD at 0.05 level of probability as described by Snedecor and Cochran (1980) and using CoStat Software Program (2008) Version 6.40.

\section{EXPERIMENTAL RESULTS}

Grapevine is subjected to the infection with powdery mildew caused by Uncinula necator (Schwe in Burr). Grapevine is the major fruits crop in commercial fields in Egypt. Grapevine is liable to be attacked by many different pathogens causing large losses in yield i.e., powdery and downy mildews and others. Powdery mildew is a worldwide economically important fungal disease in the grapevine farms and the most enduring and wide spread problem. It crop losses and intensive usage of fungicides for its control. this fungus attacks buds, leaves and fruits causing considerable yield losses. Powdery mildew symptoms can be seen on foliage, fruit, flower parts and canes. Mildew usually appears first as whitish or greenish-white powdery patches on the undersides of basal leaves, as well as leaf curling and withering. Lateral shoots are very susceptible. Infected blossoms may fail to set fruits. Berries are most susceptible to infection during the first three to four weeks after bloom, but shoots, petioles and other cluster parts are susceptible all season. Old infections appear as reddish brown areas on dormant canes. Early powdery mildew infections can cause reduced berry size and reduced sugar content. The aim of this work is to study the distribution of this disease in three different Egyptian governorates and to achieve an environmental (Fig. 2 and 3).

\section{Pathogenicity and sensitivity test of different grape cultivars to Uncinula necator infection:}

To investigate the varietal reaction of grape cultivar to infection with Uncinula necator under open field conditions was two cultivars (Rumy Ahmer and Thompson seedless) were involved into these studies. After 15 days from transplanting were inoculated with Uncinula necator the causal organism of powdery mildew symptoms were noticed 
after seven days from inoculation on the susceptible grape cultivars (Rumy Ahmer and Thompson seedless) symptoms began to appear on the leaves and fruits. The percentage of Uncinula necator infection was calculated when the first powdery mildew symptoms appeared tell reaching its maximum, the average was recorded.

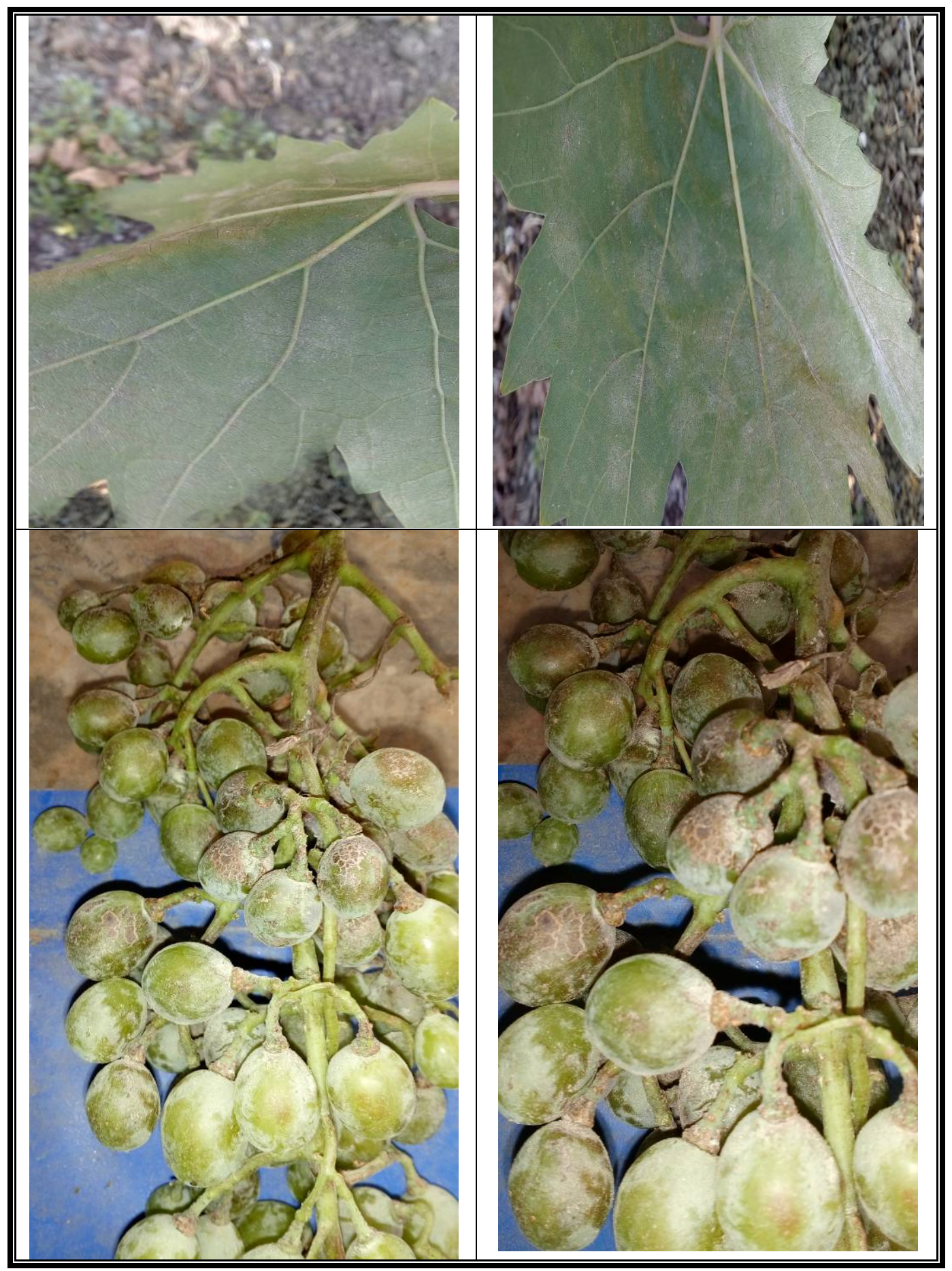

Fig. (2). Powdery mildew disease symptoms as shown on Rumy Ahmer grape leaves and fruits. 
E.Z. Khalifa, et al.,

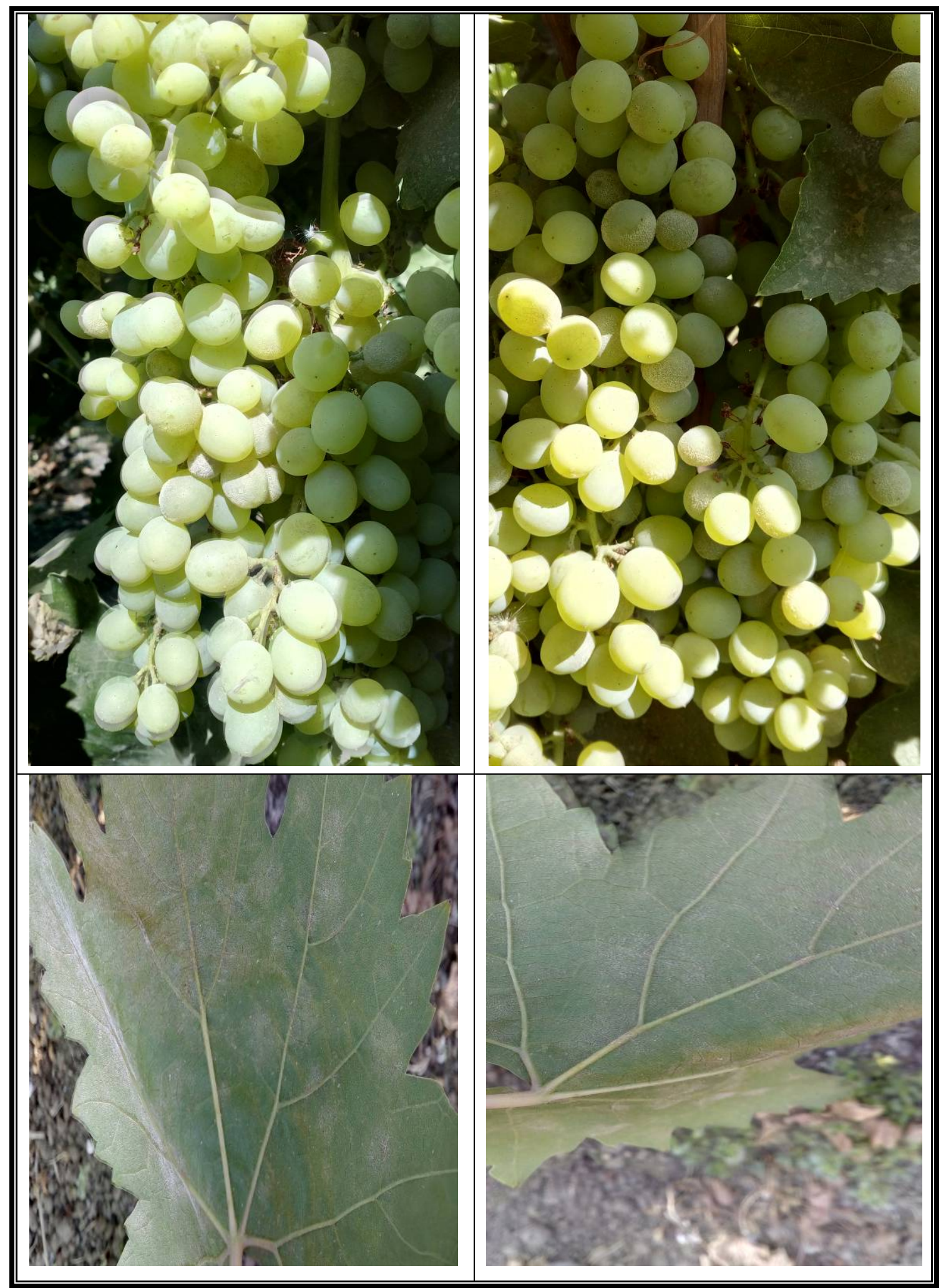

Fig. (3). Powdery mildew disease symptoms as shown on Thompson seedless grape leaves and fruits. 
Data in Table (3) and Fig. (4) indicate that the highest percentage of infection and severity of infection were significant higher in the southern governorates (Bani Suwayf and Al Minya) than obtained in the northern ones (Al Gharbiyah).

\section{DNA analysis:}

Genomic DNA prepared from three Uncinula necator isolates from three different locations (Bani Suwayf, Al Minya and Al Gharbiyah). They were used to screen primer for readily detectable and reproducible polymorphic PCR amplification. The PCR conditions employed in this study allowed amplification of many bands on the agarose gel. Bands present in each sample were scored for presence and absence of amplification products. Three primers was chosen to screen the three $U$. necator isolates, had proven to detect polymorphism in the absence or presence of specific nucleotide in isolates. These primers are widely used in the RAPD experiments. UPGMA (Dendrogram with Homology Coefficient $3.0 \%$ ) divided the three isolates into two clusters (Fig. 4). The first cluster included two isolates (Al Minya and Bani Suwayf) and the second cluster present just on isolates (Al Gharbiyah).

Generally the first cluster included two aggressive isolates with high similarity (100\%) from (Bani Suwayf and Al Minya). On the other hand, the weakest isolate from (Al Gharbiyah) was genetically different from the first cluster by $50 \%$.

\section{Effect of some antioxidants on powdery mildew disease incidence and yield production of Thompson seedless and Rumy Ahmer grape cultivars (2015 and 2016 seasons):}

Three antioxidants i.e., citric acid, ascorbic acid and boric acid were used in this study. Each antioxidant was applied in two concentration i.e., 1 and $2 \mathrm{gm} / \mathrm{L}$. These antioxidants were applied as foliar spray on grape plants for four times with 15 days intervals. Grape susceptible genotype (Thompson seedless and Rumy Ahmer) was planted in field and exposed to natural infection under field conditions. Data in Table (4) illustrate that, spraying grape plants with antioxidants greatly affected powdery mildew disease incidence and untreated grape plants (control).

Table (3). Response of different grape cultivars to Uncinula necator infection under open field conditions.

\begin{tabular}{|c|c|c|c|c|}
\hline \multirow{2}{*}{ Cultivars } & \multicolumn{2}{|c|}{ Rumy Ahmer } & \multicolumn{2}{c|}{ Thompson seedless } \\
\cline { 2 - 5 } Isolates & Infection (\%) & $\begin{array}{c}\text { Disease } \\
\text { severity (\%) }\end{array}$ & $\begin{array}{c}\text { Infection (\%) } \\
\text { Disease } \\
\text { severity (\%) }\end{array}$ \\
\hline Isolate (A) & 72.0 & 36.0 & 70.0 & 32.0 \\
\hline Isolate (B) & 62.0 & 30.0 & 47.0 & 35.0 \\
\hline Isolate (C) & 45.0 & 22.5 & & 24.0 \\
\hline
\end{tabular}

Isolate (A): Refer to isolate in Al Minya.

(B): Refer to isolate in Bani Suwayf.

(C): Refer to isolate in Al Gharbiah. 


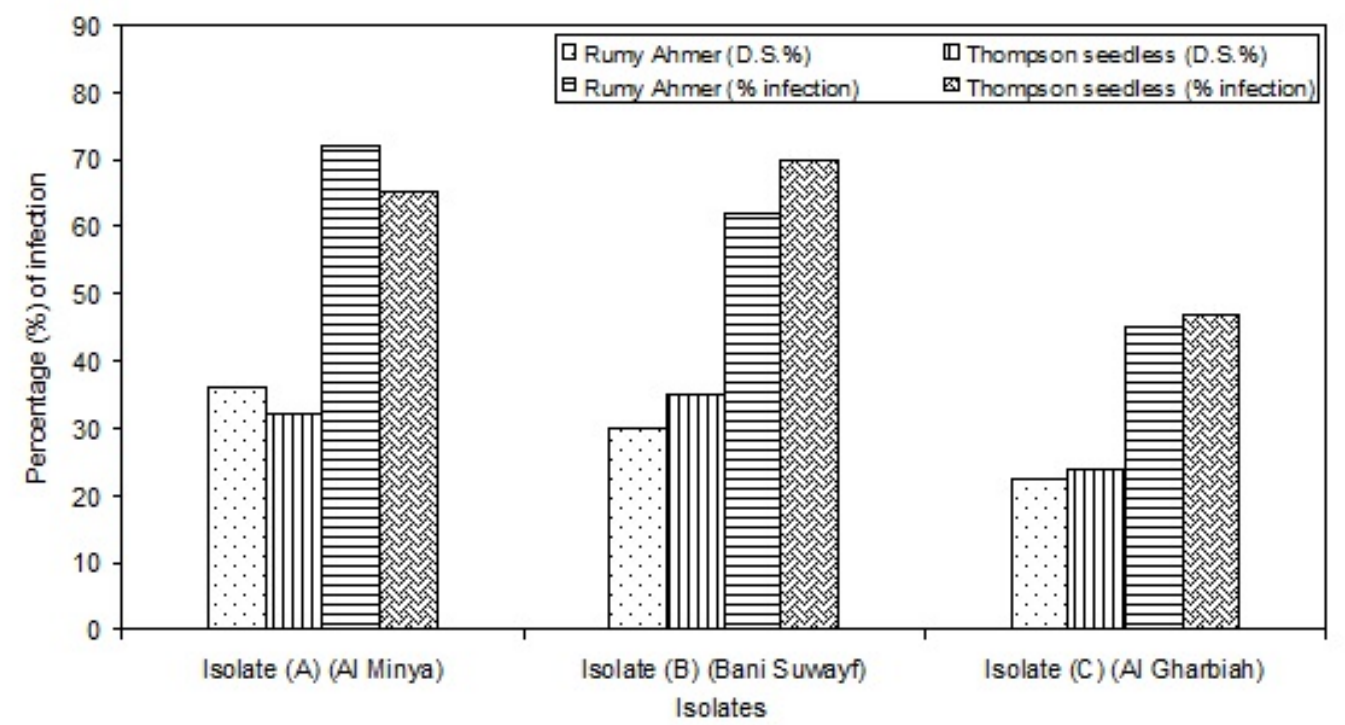

Fig. (4). Response of different grape cultivars to Uncinula necator infection under open field conditions.

Data in Table (4) indicate that spraying of grape plants with both concentrations of each one of the tested antioxidant salts affected disease severity of powdery mildew and percentage of infection (\%) during 2015 season. The most effective antioxidant was ascorbic acid (in both 1 and $2 \mathrm{gm} / \mathrm{L}$ concentration). Where the recorded disease severity were $\mathbf{1 5 . 5}$ and $14.0 \%$, while infection were 31.0 and $28.0 \%$ in 1 and $2 \mathrm{gm} / \mathrm{L}$, respectively, followed by citric acid which scored 20.0 and 14.5 while infection were 40 and $29 \%$, respectively. The least effective antioxidant was boric acid in both applied concentration, where it gave 22.5 and $17.0 \%$ for disease severity and 45.0 and $34.0 \%$ of infection, respectively.

Generally, antioxidants decreased disease parameters and increased fruit yield comparing to control treatment that resulted disease severity $40 \%$ and percentage of infection $80 \%$. Data in Table (4) illustrated the results of spraying grape plants with antioxidants solutions during 2016 season. The same trend of results that obtained during 2015 season was confirmed the obtained data during 2016 season.
The comparison between two cultivars (Rumy Ahmer and Thompson seedless) showed that Thompson seedless better than Rumy Ahmer in decreased disease severity and percentage of infection (Table 4 and Fig. 5).

\section{DISCUSSION}

Grapevine (Vitis vinefera L.) is one of the most important fruit crops all over the world, especially in tropical regions. The Egyptian grapes are very important both for local consumption and exportation. The cultivated area of grapes in Egypt reached 164105 feddans which produced the average of 1360251 tons (Statistics Dept. Ministry of Agriculture, Egypt, 2011). Powdery mildew treatments the yield in the highest degree because it require specific weather condition, i.e. less relative humidity and a higher temperature conditions for infection (Angeli et al., 2006), our study is agreed with this hypothesis, the obtained results cleared that severity of infection with powdery mildew disease incidence was higher at southern governorates (Bani suwayf and Al Minya) than the northern one (Al Gharbiya). 
Table (4). Comparison effect of some antioxidants on powdery mildew disease between Rumy Ahmer and Thompson seedless cultivars (2015 and 2016 seasons).

\begin{tabular}{|c|c|c|c|c|c|c|c|c|}
\hline \multirow[b]{2}{*}{$\begin{array}{l}\text { Anti- } \\
\text { oxidant (B) }\end{array}$} & \multirow{2}{*}{ 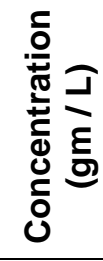 } & \multicolumn{3}{|c|}{ Disease severity (\%) } & \multicolumn{3}{|c|}{$\%$ of infection } & \multirow{2}{*}{$\begin{array}{c}\text { Yield } \\
\text { (kg/plant) }\end{array}$} \\
\hline & & $\begin{array}{l}\text { Rumy } \\
\text { Ahmer }\end{array}$ & $\begin{array}{c}\text { Thompson } \\
\text { seedless }\end{array}$ & Mean & $\begin{array}{l}\text { Rumy } \\
\text { Ahmer }\end{array}$ & $\begin{array}{c}\text { Thompson } \\
\text { seedless }\end{array}$ & Mean & \\
\hline \multirow{2}{*}{ Ascorbic acid } & 1 & 19.0 & 15.5 & 17.25 & 38.0 & 31.0 & 34.50 & 18.25 \\
\hline & 2 & 12.5 & 14.0 & 13.25 & 25.0 & 28.0 & 26.60 & 22.25 \\
\hline \multirow{2}{*}{ Citric acid } & 1 & 21.2 & 20.0 & 20.70 & 42.4 & 40.0 & 41.20 & 16.75 \\
\hline & 2 & 16.8 & 14.5 & 15.65 & 33.6 & 29.0 & 31.30 & 19.00 \\
\hline \multirow{2}{*}{ Boric acid } & 1 & 24.0 & 22.5 & 23.20 & 48.0 & 45.0 & 46.50 & 14.75 \\
\hline & 2 & 19.5 & 17.0 & 18.20 & 39.0 & 34.0 & 36.50 & 17.90 \\
\hline Control & - & 34.0 & 40.0 & 37.00 & 68.0 & 80.0 & 74.00 & 11.75 \\
\hline Mean & - & 21.011 & 20.485 & - & 42.000 & 41.020 & - & 17.25 \\
\hline \multirow[t]{3}{*}{ L.S.D. at 0.05} & A & \multicolumn{3}{|c|}{0.471} & \multicolumn{3}{|c|}{1.330} & \\
\hline & B & \multicolumn{3}{|c|}{1.430} & \multicolumn{3}{|c|}{2.637} & \\
\hline & $A \times B$ & \multicolumn{3}{|c|}{2.022} & \multicolumn{3}{|c|}{3.720} & \\
\hline
\end{tabular}

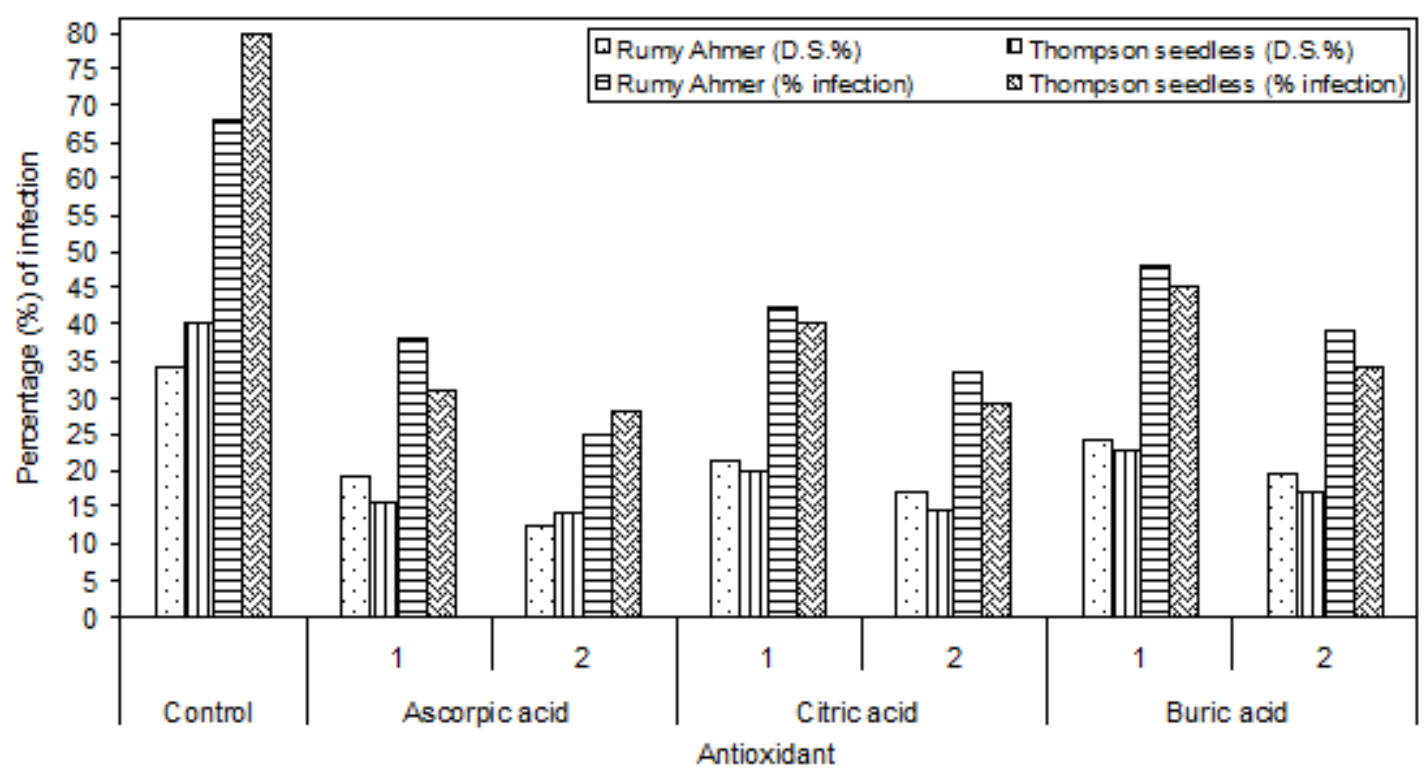

Fig. (5). Comparison effect of some antioxidants on powdery mildew disease between Rumy Ahmer and Thompson seedless cultivars. 
Ocete et al. (2002) reported that the main damages on the aerial part were caused by the perineum strain of coolers vitas. Symptoms caused by powdery mildew (Uncinula necator) were often observed on leaves, clusters and shoots in spring and summer.

The powdery mildew disease incited by Uncinula necator. Amaud is one of the major problems facing grapes production.

Powdery mildew occurs all over the world and cultivated plants (Spencer 1978).

Powdery mildew on grapes is very important in countries where hot summer, high temperature and high relative humidity are prevalent.

Osman (1977) noticed the symptoms of powdery mildew appeared as yellow spots on the upper leaf surface while on the corresponding lower surface white patches. However, different aspects of symptoms on different hosts were observed. Pearson and Gadoury (1987) reported that in spring, the first powdery mildew colonies were consistently found on leaves of shoots $(7-30 \mathrm{~cm})$ growing close to exfoliating bark on the head and trunk of the vine. Cleistothecia were found in spring on all Plant Parts Infected during the previous growing season and also in leaf scars and in crevices of exfoliating bark. Most (79-97\%) of the cleistothecia borne on leaves, canes and cluster stems died during winter and spring without releasing ascosperes.

Cleistothecia are confirmed as the main inoculums sources for primary winter and spring infections and latent mycelium in buds appear to provide inoculums for the secondary spring infection (Pezet and Bolay, 1992).

Demir and Kotan (2016) stated that Uncinula necator (Sch.) Burrill is the obligate fungal pathogen responsible for powdery mildew on grapevine (Vitis vinifera L.). The disease is found in most grape-growing areas of the world and is one of the most widespread and destructive disease of grapevine.

Survey of powdery mildew disease incidence was carried out during 2015 growing season. Three different governorates i.e., Gharbia, Bani Suwayf and Al Minya were chosen for this survey which conducted four times, 15 days interval from June $5^{\text {th }}$ to August $5^{\text {th }}$. Results of study clear that severity of infection with Uncinula necator was increased by delaying time of estimation. It was also noticed that powdery mildew disease incidence was lower at northern governorates (Al Gharbia) than the southern ones (Bani Suwayf and Al Minya). At the same dates, these were 10 $-28 \%, 25-38 \%$ and $35-57 \%$ at Gharbia, Bani Suwayf and Al Minya governorates, respectively. Such results clear that powdery mildew disease of grapes was more favored by high temperature.

To investigate the varietal reaction of grape cultivar to infection with Uncinula necator under open field conditions. Two cultivars (Rumy Ahmer and Thompson seedless) were involved in these studies. After 15 days from transplanting were inoculated with Uncinula necator; the causal organism of powdery mildew; symptoms were noticed after seven days from inoculation on the susceptible grape cultivars (Rumy Ahmer and Thompson seedless) symptoms began to appear on the leaves and fruits. The percentage of Uncinula necator infection was calculated when the first powdery mildew symptoms appeared tell reaching its maximum, the average was recorded.

The highest percentage of infection and severity of infection were significant higher in the southern governorates (Bani Suwayf and Al Minya) than that obtained in the northern ones (AI 
Gharbia).

To demonstrate the sensitivity of the tested varieties, the pathogenicity test was conducted at healthy (RumyAhmer and Thompson seedless) cultivars to Uncinula necator infection; the susceptibility of both cultivars to both fungal isolates was confirmed with high degrees of infection, the morphological characters of conidia and conidiophores observed in the present investigation are in agreement with the descriptions given by Heffer et al. (2006) and Braun et al. (2002). Also, these results are consistent with the results of Doster and Schnathorst (1985), where it was Thompson Seedless the most susceptible cultivar to powdery mildew disease on growth chamber and field experiments.

The differentiation between three $U$. necator isolates from three different locations, using molecular biology techniques showed that the most two aggressive isolates have a high degree of genetic affinity reaches the extent of similarity, where the first cluster contains the most two aggressive isolates from (Bani Suwayf and Al Minya) with a degree of genetic similarity up to $100 \%$. On the other hand, the weakest isolate from (Gharbia) showed a high genetic variation with a difference up to $50 \%$ for the previous isolates.

The antioxidants were significantly better improving disease control and fruit yield production of strawberry than the control salicylic acid and ascorbic acid were the most effective antioxidants on wilt disease and increasing the yield (Mansour, 2005 and El-Kolaly, Ghada, 2003).

Spraying grape plants with antioxidants greatly affected powdery mildew disease incidence and untreated grape plants (control).

Also, spraying of grape plants with both concentrations of each one of the tested antioxidant salts affected disease severity of powdery mildew and percentage of infection (\%) during 2015 season. The most effective antioxidant was ascorbic acid (in both 1 and $2 \mathrm{gm} / \mathrm{L}$ concentration). Where the recorded disease severity were 15.5 and $14.0 \%$, while infection were $\mathbf{3 1 . 0}$ and $\mathbf{2 8 . 0 \%}$ in 1 and $2 \mathrm{gm} / \mathrm{L}$, respectively, followed by citric acid which scored 20.0 and $\mathbf{1 4 . 5 \%}$ while infection were 40 and $29 \%$, respectively.

Generally, antioxidants decreased disease parameters and increased fruit yield comparing to control treatment that resulted disease severity $40 \%$ and percentage of infection $80 \%$. The results of spraying grape plants with antioxidants solutions during 2016 season. The same trend of results that obtained during 2015 season was confirmed the obtained data during 2016 season.

\section{REFERENCES}

Abd-Elsalam, A., Amal K.A. Asran and A. El-Samawaty (2007). Isolation of DNA from cotton and its fungal pathogens high quality. Journal of Plant Diseases and Protection, 114: 113 - 116.

Angeli, D., L. Maines and I. Pertot (2006). Efficacy evaluation of integrated strategies for powdery and downy mildew control in organic viticulture. Bulletin-OILB/SROP, 29 (11): 51 - 56.

Braun, U., R.T.A. Cook, A.J. Inman and H.D. Shin (2002). The Taxonomy of the Powdery Mildew Fungi. Pages 13-55 in: The Powdery Mildews: a Comprehensive Treatise, Berlanger, R.R., W.R. Bushnell, A.J. Dik, and T.L.W Carver (eds.). American Phytopathological Society, St Paul.

Cerkauskas, R.F., G. Ferguson and M. Banik (2011). Powdery mildew Levelillula taurica on greenhouse and field peppers in ontano-host range, cultivar response and disease 
management strategies. Canadia Journal of Plant. Pathology, 33 (4): 485 $-489$.

CoStat Software Program (2005). User's Manual Version 6.311 CoHort. Tusson, Arisona, U.S.A.

Demir, G. and R. Kotan (2016). Control of powdery mildew (Uncinula necator, Schw.) disease with bacterial biocontrol agents. Turkiye Biyolojik Mucadele Dergisi, 7 (1): 13 - 30.

Doster, M.A. and W.C. Schnathorst (1985). Comparative Susceptibility of Various Grapevine Cultivars to the Powdery Mildew Fungus Uncinula Necator. Am. J. Enol. Vitic. January 1985, 36: 101 - 104.

El-Kolaly, Ghada A.A. (2003). Pathological studies on root and crown roles of strawberry in Egypt. Ph.D. Thesis, Faculty of Agriculture, Cairo University, p. 151.

Heffer, V., K.B. Johnson, M.L. Powelson and N. Shishkoff (2006). Identification of Powdery Mildew Fungi Anno 2006. The Plant Health Instructor.

Horsfall, J.G. and R.W. Barratt (1945). An improved grading system formeasuring plant diseases. Phytopathology, 35: 655.

Kremer, W. and G. Unterstanhofer (1967). Compution of results of crop protection experiments by the methods of Townsend and Huberger. Pflanzenschut Nachrichten "Bayer", 20: $625-628$.

Mansour, A.S. (2005). Pathological studies of wilt diseases on strawberry in Egypt. Ph.D. Thesis, Faculty of Agriculture, Moshtohor, Benha University, p. 157.

Ocete, R., M. Cantos, M.A. Lopez, I. Gomez and A. Troncoso (2002). Wild grapevine populations in the OssaMorena Mountain Range (PortugalSpain): Location, Characterization and Sanitary State. Vitas, 2002, 41 (1): 55 56.

Osman, H.A. (1977). Studies on Leveillula taurica the incitant of powdery mildew in solanacerous plants. M.Sc. Thesis, Fac. of Agric., Menoufiya University, A.R.E.

Pearson, R.C. and D.M. Gadoury (1987). Cleistothecia, the source of primary inoculum for grap powdery mildew in New York. Phytopathology, 77 (11): 1509 - 1514.

Pezet, R. and A. Bolay (1992). Powdery mildew on grape: Presei situation and consequences for control. Revue Suisse de Viticulture, d' Arboriculture et d' Horticulure, 24 (2): 67 - 71.

Snedecor, C. W. and W. G. Cochran (1980). Statistical methods, $7^{\text {th }}$ ed. lowa State Univ. Press Ames. Iowa, USA.

Soleman, N.K., M.S. Mikhail, K.R. Herb and E.M. Khalid (1988). Response of broad been plants infected with Rizoctonia solani to application of growth regulators and calcium. Egypt's Phytopathology, 20 (1): 1 - 11.

Spencer, D.M. (1978). The powdery mildews. Acad. Press. Inc. (London) Ltd.

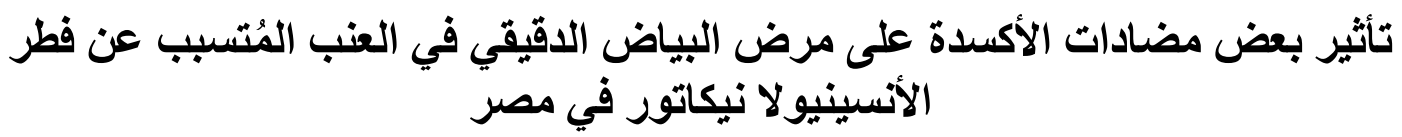




\section{السعيد زكي خليفة ، حسام محمد عوض ، هاني عبد السلام دراز قسم النبات الززراعى ـ كلية الزراعة - شبين الكوم - جامعة المنوفية}

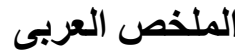

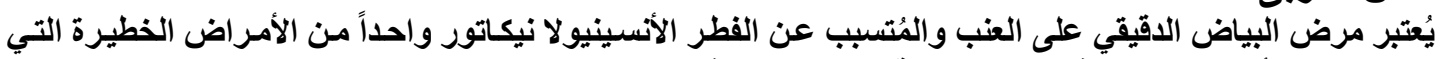

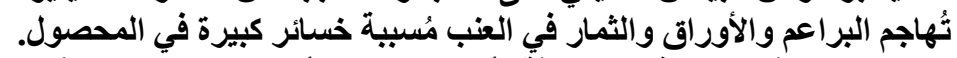

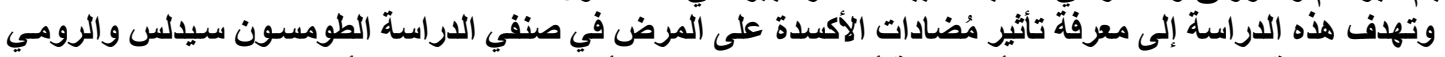

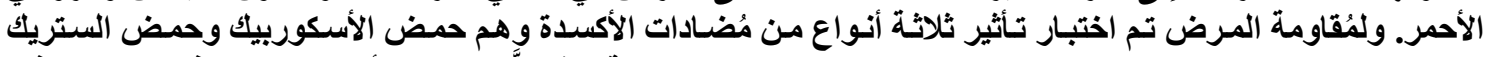

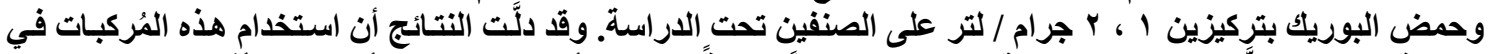

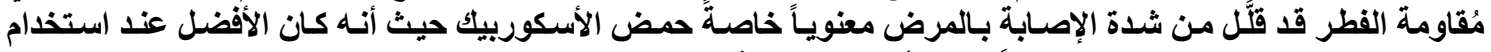

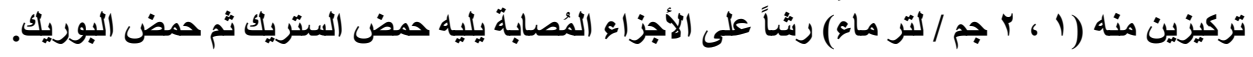

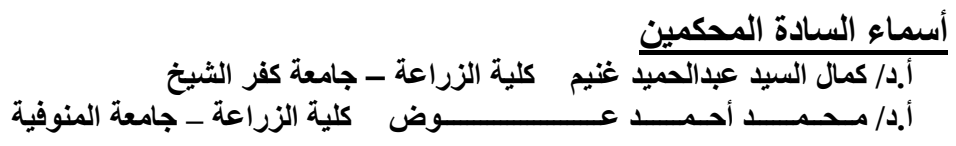

